\title{
The Effectiveness of Discovery Learning Model and Problem-Based Learning Using Animated Media to Improve Science Learning Outcomes
}

\author{
Ni Wayan Suniasih ${ }^{1 *}$ \\ ${ }^{1}$ Primary School Teacher Education Study Program, FIP, Universitas Pendidikan Ganesha, Indonesia \\ *Corresponding author.Email: niwayan.suniasih@undiksha.ac.id
}

\begin{abstract}
This research aims to determine: 1) the significant difference between groups of students who were taught using the Discovery Learning, Problem-based Learning model using animated media and the group of students who were taught conventionally; (2) magnitude of the effectiveness of Discovery Learning and Problem-based Learning models to improve science learning outcomes in fifth grade of SD Negeri Gugus II Kuta Badung. This research used quasiexperimental research with the Non-equilevalent Control Group Design. The data were collected through test techniques. The research population was seven classes of fifth grade elementary school students in SD Negeri Gugus II Kuta Badung from five elementary schools. The research sample was determined using a random sampling technique consisting of three classes. Based on the results of the One-Way Analysis of Variance obtained $\mathrm{F}_{\text {count }}=17,855$, Sig $0.000<0.05$. This means that there is a significant difference in science learning outcomes between groups of students who are taught using the Discovery Learning, Problem-based Learning model using animated media, and the group of students who are taught conventionally. Followed by calculating the effectiveness of the learning model to improve science learning outcomes using Partial Eta Squared, the results obtained Partial Eta Squared $\left(\eta^{2}\right)=0,247$. So it can be concluded that the application of the Discovery Learning, Problem-based Learning models using animated media is effective in improving science learning outcomes with an effectiveness of 0.247 in the medium category.
\end{abstract}

\section{Keywords: Discovery Learning, Problem-based Learning, Animated Media, Science Learning Outcomes}

\section{INTRODUCTION}

The 21st century learning paradigm emphasizes the ability of students to think critically, be able to connect knowledge with the real world, master information technology, and be able to communicate. Advances in information and communication technology have changed the pattern of human life, both in work, socializing, and studying. The logical consequence of this change requires schools to change learning oriented to the TPACK approach (Technological, Pedagogical, Content, Knowledge). This is in accordance with the demands of the future where students must have skills in thinking and learning. 21st century learning reflects four things known as 4C which include: (1) Communication, (2) Collaboration, (3) Critical Thinking and problem solving, and (4) Creative and Innovative [1].

All of these characters can be possessed by students if educators, in this case the teacher, are pedagogically able to motivate students, want to develop learning plans that contain activities that challenge them to think actively and critically in solving the problems given. In fact,when students are faced with questions of the level of ability to analyze, most students answer incorrectly so that their learning outcomes do not reach the minimum completeness criteria of 7.00. Students in learning are guided by the activities in their book, while the teacher assigns students according to what is in their book and is combined with the teacher's book direction. Routines like this make students bored, less fun and not challenging. In addition, teachers are also required to be creative and able to integrate the use of information and communication technology in learning activities. It is a must for teachers and students to take advantage of information technology especially in the situation of the Covid-19 pandemic which has affected the education worldwide.

The government has made efforts to improve the quality of education at every level through improving educational standards, one of which is learning activities 
directed at empowering all potential students into expected competencies. There are several innovative learning models that are recommended by the application of the Scientific Approach in integrated thematic learning, namely Problem-based Learning model, Project-based Learning model, and Discovery Learning model. The three models are expected to lead students to be able to solve problems in order to actualize their abilities in the form of integrated soft skills and hard skills. Based on the situation analysis in the field, learning facilities are available in elementary schools, especially in cluster II Kuta, such as computers (laptops) individually given to all students in grades 5 and 6 that can be brought home by students, projectors (LCD), internet and the environment as a medium or learning resource in order to fulfill the learning demands of the 21 st century but it has not been used optimally. After the Covid-19 pandemic situation occurred, it required teachers and students to use these facilities for online learning needs.

Regarding the Discovery Learning model and Problem-based Learning, there are several studies that have been carried out before such as research conducted by Nugroho [2] he compared Discovery Learning model and Problem-solving model. The results of his research found that Fcount $=36.348$ with a significance level of 0.000 . Therefore $0.000<\alpha=0.050$, it can be concluded that the Discovery Learning model is superior to the Problem-solving learning model. Another research was conducted by Rida Fironika Kusumadewi [3] found that the Discovery Learning model can improve the aspects of attitudes, knowledge, and skills with an average of 74.80 with a value conversion of $3.24(\mathrm{~B}+)$. From the research that has been done, there has not been much follow up on the influence of the Discovery Learning model and problem-based learning in teaching and learning process especially knowing the effectiveness of these models to improve learning outcomes.

In this experiment, two learning models recommended in the 2013 are Discovery Learning and Problem-based Learning combined with animated media obtained from social media YouTube. This study recommends the effectiveness of the two learning models to improve student learning outcomes, both facts and concepts in science material. Discovery Learning and problem-based learning theoretically have something in common. Those two learning models are problemoriented but have differences in the principle. Discovery Learning model is a model for developing active student learning by discovering and investigating by themselves so that the results obtained will be consistent and will not be easily forgotten by students [4]. Through the Discovery Learning model students have the opportunity to practice solving problems in the form of questions, sharpen their critical thinking independently as they have to analyze and manipulate information. The difference between the Discovery Learning and the problem based learning that is, in this model the problem is not the result of manipulating, so students must exert all their thoughts and skills to find the concept in the problem through the problem-solving process. However, the Discovery Learning model emphasizes the discovery of knowledge concepts that were previously unknown to students. The discovery problems faced by students are manipulated problems.

The experiment with these two learning models, namely the Discovery Learning model and problem based learning combined with animated media is expected to produce an effective learning model to improve science learning outcomes. For this purpose, a study entitled "The Effectiveness of Discovery Learning Model and Problem-based Learning Using Animated Media to Improve Science Learning Outcomes" in fifth grade elementary students of SD Negeri Gugus II Kuta Badung.

\section{THEORETICAL REVIEW}

\subsection{Science Learning Outcomes}

Learning outcomes are competencies or abilities both cognitive, affective and psychomotor that are achieved by students after experiencing the learning process [5]. The success of students in learning is measured through the achievement of competencies stated in the 2013 curriculum which is known as core competencies which include core competencies in attitudes, core competencies of knowledge and core competencies of skills.

Science learning outcomes are measured based on the attainment of competence, both knowledge attitudes and skills of students after experiencing the science learning process. This is known from the results of the assessment of students including; (1) able to understand the concept that underlies the science competence that must be mastered or achieved which is contained in the basic competencies specified through indicators, (2) able to do work in accordance with the demands of the science competency that must be achieved and correct procedures and good results, (3) able to apply their abilities in everyday life in the science learning process.

\subsection{Discovery Learning Model}

Discovery Learning is one of the learning models used in the modern constructivist approach. In this learning, students are encouraged to learn on their own through active skills with various concepts and principles. According to Kodir [4], the Discovery Learning model is "a model for developing active student learning by discovering and investigating for themselves so that the results obtained will be loyal and will not be easily forgotten by students". The Discovery Learning model is a learning model that emphasizes students to 
find their own concept of knowledge and this model directs students to be able to find something through the learning process they do. Through Discovery Learning, students are expected to be involved in investigating a relationship, collecting data, and using it to discover laws or principles that apply to the some problems.

The concept of Discovery Learning is actually not much different from the Problem-based Learning Model. Both are learning strategies that emphasize the process of concept discovery by students themselves. However, Discovery Learning places more emphasis on finding knowledge concepts that were previously unknown to students. In Discovery Learning, students are faced with problems that are specifically designed or manipulated by the teacher. These problems are adjusted to the competencies and concepts of knowledge to be achieved. It should also be noted by the teacher that in designing problems, they should be adapted to conditions, phenomena, objects, or situations that exist at that time.

In the application of Discovery Learning, the teacher must position himself as a guide for students in carrying out investigations. Teachers are also required to provide the widest possible opportunity for students to actively explore in finding their knowledge. As much as possible in this lesson, students can answer their curiosity about the concepts learned through exploration. Based on the opinion regarding Discovery Learning, it can be summarized that the Discovery Learning model is student-centered learning to develop active student learning by discovering and investigating the concepts that are packaged in a given problem / problem.

According to Kodir [4] the steps (syntax) of implementing the Discovery Learning model.

Table 1. Syntax of Discovery Learning Model

\begin{tabular}{|ll|l|}
\hline \multicolumn{2}{|c|}{ Stages } & \multicolumn{1}{|c|}{ Teacher Activities } \\
\hline 1. $\begin{array}{l}\text { Explain the purpose } \\
\text { prepare students }\end{array}$ & $\begin{array}{l}\text { Delivering learning objectives; motivate students to } \\
\text { be involved in activities. }\end{array}$ \\
\hline $\begin{array}{l}\text { 2. } \\
\text { Student orientation } \\
\text { to the problem }\end{array}$ & $\begin{array}{l}\text { Provide simple problems with regard to learning } \\
\text { materials. }\end{array}$ \\
\hline 3. $\begin{array}{l}\text { Formulate a } \\
\text { hypothesis }\end{array}$ & $\begin{array}{l}\text { Guiding students in formulating hypotheses in } \\
\text { accordance with existing problems. }\end{array}$ \\
\hline 4. & $\begin{array}{l}\text { Doing discovery } \\
\text { activities }\end{array}$ & $\begin{array}{l}\text { Guiding students to do discovery activities by } \\
\text { directing students to obtain the necessary } \\
\text { information. }\end{array}$ \\
\hline $\begin{array}{l}\text { 5. } \\
\text { Present the results } \\
\text { of discovery } \\
\text { activities }\end{array}$ & $\begin{array}{l}\text { Guiding students in presenting the results of } \\
\text { activities, formulating conclusions / finding } \\
\text { concepts. }\end{array}$ \\
\hline $\begin{array}{l}\text { 6. } \\
\text { Evaluating } \\
\text { discovery activities }\end{array}$ & $\begin{array}{l}\text { Evaluating the activity steps that have been carried } \\
\text { out. }\end{array}$ \\
\hline
\end{tabular}

\subsection{Problem-based Learning Model}

Problem-based Learning is an innovative learning model that can provide active learning conditions for students in its delivery by presenting a problem, asking questions, facilitating investigations, and opening dialogue. The problems studied are conceptual problems found by students in everyday life. Problems must be solved by applying several concepts and principles that are simultaneously studied and included in the subject curriculum.

The characteristics of the Problem-based Learning model are (1) the existence of asking questions or problems, (2) focusing on interdisciplinary linkages, (3) authentic investigations, (4) producing products or works and presenting them, and (5) cooperation. Problem-based Learning has the following characteristics (1) learning begins with a problem, (2) ensures that the problem given relates to the real world of students, (3) coordinates lessons around the problem, (4) provides responsibility Big responsibility to learners in forming and directly carrying out their own learning process, (5) using small groups, and (6) requires students to demonstrate what they have learned in the form of a product or performance. Thus it can be said that Problem-based Learning is a problem-solving-oriented learning model that is integrated with real life so that students can form their own knowledge so it can be used to train students' thinking ability.

Learning activities using the Problem-based Learning model begin with a problem, then students deepen their knowledge of what is already known and what needs to be known to solve the problem. Problems that are used as the focus of learning can be solved by students through group work so that they can provide learning experiences for students such as collaboration and interaction in groups. Problem-based Learning can increase students' understanding of what is being learned so that students can apply it in real conditions in everyday life.

The Problem-based Learning model has several steps in its implementation in learning. The steps of the Problem-based Learning model are (1) clarifying unclear concepts, (2) formulating problems, (3) analyzing problems, (4) organizing ideas systematically, (5) formulating learning objectives, (6) seeking additional information from other sources, and (7) synthesizing and testing new information, making reports for the teacher or class [6].

There are five main stages in Problem-based Learning which begin with introducing students to the problem which ends with the stages of presenting and analyzing student work. The five stages will be presented in table 2 below. 
Table 2. Syntax Table for Problem-based Learning Model

\begin{tabular}{|l|l|l|}
\hline Phase & Indicator & Teacher activities / activities \\
\hline 1 & $\begin{array}{l}\text { Student orientation to the } \\
\text { problem }\end{array}$ & $\begin{array}{l}\text { The teacher explains the learning objectives, explains the logistics } \\
\text { required, poses problems, motivates students to engage in problem- } \\
\text { solving activities of their choosing. }\end{array}$ \\
\hline 2 & $\begin{array}{l}\text { Organize } \\
\text { students to learn }\end{array}$ & $\begin{array}{l}\text { The teacher helps students define and organize learning tasks related to } \\
\text { these problems. }\end{array}$ \\
\hline 3 & $\begin{array}{l}\text { Guiding individual } \\
\text { group investigations }\end{array}$ & $\begin{array}{l}\text { The teacher encourages students to collect appropriate information, carry } \\
\text { out experiments, to get problem solving explanations. }\end{array}$ \\
\hline 4 & $\begin{array}{l}\text { Develop and present the } \\
\text { work }\end{array}$ & $\begin{array}{l}\text { The teacher assists students in planning and preparing appropriate work } \\
\text { such as reports, videos, models, and helps them to share assignments with } \\
\text { the group. }\end{array}$ \\
\hline 5 & $\begin{array}{l}\text { Analyzes and evaluates } \\
\text { the problem-solving } \\
\text { process }\end{array}$ & $\begin{array}{l}\text { The teacher helps students reflect or evaluate their investigations into the } \\
\text { processes they use. }\end{array}$ \\
\hline
\end{tabular}

\subsection{Animated Media}

Media comes from Latin, namely medium, which means intermediary can be used as the sender of information and also the recipient of information [7]. If the media carries information about teaching, then the media can be said to be learning media. The learning media used can be varied but can attract students' enthusiasm in learning, one of which is animated media. Animation is a creative form of the 21 st century that informs many aspects ranging from feature films to web cartoons [8]. Animation is multimedia that can convey information and learning content in the form of animated images combined with text, sound, attractive colors to create animated videos that are in accordance with the learning material. Animation is not just movement alone, it can also be how and what changes, changes that occur by the subjects displayed by the makers. Using animated media can attract students' attention and enthusiasm in learning since the animation is not only limited to move pictures but is supported by unique and beautiful sounds also colors that are in harmony and the images used are cartoons that illustrate these movements and convey a message or purpose from the learning that will be obtained by students.

There are two types of animation application, namely animation in non-digital form and in digital form. Animations in non-digital form only display images and movements in print or on paper. Meanwhile, digital animation will display the moving images using digital so that it looks real. Thus, animation is very good to be used for elementary school children because it will attract their attention and enthusiasm in learning. Animations in learning using existing ones are obtained from social media.

\section{METHOD}

This type of research is a quantitative research with a quasi experimental design. The population in this study was fifth grade students in cluster II Kuta Badung totaling 7 classes from five elementary schools with 222 students. The research sample was determined through the cluster random sampling technique, namely three classes totaling 112 people.

The design used involved three class groups, namely two experimental groups that were treated with the Discovery Learning model using animated media and Problem-based Learning using animated media and one conventional learning class as the control group. The quasi-experimental design used in this study was a modified Nonequilevalent Control Group Design. It is formulated as follows.

\begin{tabular}{|ccc|}
\hline $\mathrm{O}_{1}$ & $\mathrm{X}_{1}$ & $\mathrm{O}_{2}$ \\
$\mathrm{O}_{3}$ & $\mathrm{X}_{2}$ & $\mathrm{O}_{4}$ \\
\hline $\mathrm{O}_{5}$ & & $\mathrm{O}_{6}$ \\
\hline
\end{tabular}

Figure 1 Nonequilevalent Control Group Design (Source: Sugiyono, 2018: 79)

Information:

$\mathrm{O} 1=$ Pre-test in the experimental group

$\mathrm{O} 2$ = Post-test in the experimental group

O3 = Pre-test in the experimental group

$\mathrm{O} 4=$ Post-test in the experimental group

O5 = Pre-test in the control group

O6 = Post-test in the control group

$\mathrm{X}=$ Treatment diberikan in the experimental group. The treatment was given to 2 experimental groups, namely: X1 was given treatment in the form of Discovery Learning and X2 given treatment in the form of Problem-based Learning model.

The pre-test was given to the control group and the experimental group. For the two groups the experimental class was given learning model Discovery Learning and Problem-based Learning using animated media, while the control group had no intervention or no treatment. Then after being given the treatment, a post test was carried out to determine the results of learning science on aspects of knowledge about the respiratory system. For the attitude aspect, discipline and responsibility were recorded in doing tasks, but were not analyzed as research data. The experiment is planned in three stages, namely: the preparation stage, the implementation stage, and the final stage of the experiment.

\section{a. Experiment Preparation Stage}

In the preparation stage the activities carried out are as follows.

1) Obtaining information from the principal in Cluster II Kuta Badung and fifth grade students homeroom teachers in each school to find out 
about the class conditions in each Cluster II for the 2019/2020 academic year.

2) Preparing learning support facilities such as compiling lesson plan, learning resources (LKPD) and animated media used in the learning process. Develop a research instrument in the form of a science learning outcome test.

3) Determine the research sample from the population.

4) Giving pre-test to three selected class groups to be the sample.

b. Implementation Stage

At the time of implementing the experiment the steps were carried out as follows.

1) Providing treatment to the experimental group in the form of Discovery Learning and Problembased Learning models and the control group taught conventionally.

2) Provide a post test at the end of the experiment, both in the control and experimental groups

3) The process of giving treatment to the experimental group was 6 meetings.

\section{c. Final Stage}

At the final stage of the experiment, the activities carried out are:

1) Analyze research data.

2) Carry out hypothesis testing.

The data collection technique used in this study was a test. Test is a specific and systematic procedure for measuring a person's behavior or an objective measurement of recognizing someone's behavior, so that behavior can be described with the help of numbers, scales or with a category system [9]. The test technique is used to obtain data on science learning outcomes on knowledge of the respiratory system. The test used is given at the end of the experiment in accordance with the research design designed. In this study, the test used to measure science learning outcomes was multiple choice test, equipped with a journal for collecting student assignments that are used to collect data on learning outcomes in the form of competency attitudes and skills in learning science.

The analysis technique used to analyze the science learning outcomes data in this study is inferential statistics. Inferential statistics are statistics used to analyze sample data, and the results will be generalized (referenced) for the population where the sample is taken [10]. The data used to be analyzed is the normalized score gain data from the pre-test and post-test results. The gains score formula is as follows.

Score Gain =

Science learning outcomes data from this study were analyzed using one way ANOVA. Anova is part of the comparative analysis method of more than two averages. The goal of a one-way Anova is to compare more than two means. In this study, three groups of data averages were tested, namely the results of science learning that were taught using the Discovery Learning model, the Problem-based Learning model using animated and conventional learning media. Therefore the statistical hypothesis tested is as follows:

$$
\begin{aligned}
& \text { Ho: } \mu \mathrm{A} 1=\mu \mathrm{A} 2=\mu \mathrm{A} 3 \\
& \mathrm{H} 1: \text { at least two means are not equal or } \\
& \mathrm{H} 1 \text { : at least one sign }=\text { not valid }
\end{aligned}
$$

To determine the effectiveness of the Discovery Learning model and the Problem-based Learning model in improving science learning outcomes, the Effect Size (SE) is used) Partial Eta Squared. The criteria for determining effectiveness are as follows

$=$

Information:

$\eta^{2}=$ eta squared

SSeffect $=$ proportion of effect variance

SSError = Error variance proportion

ICE $\leq 0.20 \ldots \ldots \ldots \ldots$ low effectiveness

$0.20<\mathrm{ES} \leq 0.80 \ldots \ldots \ldots$ moderate effectiveness

$0.80<\mathrm{ES} \ldots \ldots \ldots \ldots \ldots$ high effectiveness

The hypothesis of this study is there is a significant difference in science learning outcomes between groups of students who are taught through Discovery Learning models, Problem-based Learning models using animated media, and groups of students who are taught conventionally in fifth grade students in elementary school Cluster II Kuta Badung Academic Year 2019/2020.

\section{FINDING AND DISCUSSION}

\subsection{Data Description}

Science learning result data on the aspect of knowledge competence in this study is a normalized score gain. The data, both in groups that were taught using the Discovery Learning model, the Problem-based Learning model, and those that were taught conventionally were analyzed using one-way ANOVA. The following shows the data from each of these groups.

\subsubsection{Description of fifth grade students in Science Learning Outcomes Data}

The group of students taught by the Discovery Learning Model used animated media. Fifth grade students in SDN No. 2 Legian was taught using the Discovery Learning Model 6 times. Description of the normalized score gain data is presented in table 3 below. 
Table 3. Description of Student Group Science Learning Outcomes who were taught with the Discovery Learning Model

\begin{tabular}{|c|c|c|c|c|c|c|c|c|}
\hline & $\mathrm{n}$ & Range & $\begin{array}{l}\text { Score } \\
\text { Min }\end{array}$ & Score Max & Sum & Mean & Std. Deviation & Varriance \\
\hline 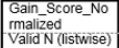 & \begin{tabular}{r|}
38 \\
38 \\
\end{tabular} & 0.64 & 0.36 & 1.00 & 29.02 & 0.764 & 0.164 & 0.027 \\
\hline
\end{tabular}

Based on the data in table 3 , it can be seen that the number of students or $\mathrm{n}=38$, the minimum score is 0.36 , the maximum score is 1.00. Furthermore, Mean 0.764, standard deviation 0.162 , and Variance 0.027. Below is the data presented in the form of a histogram in Figure 2.

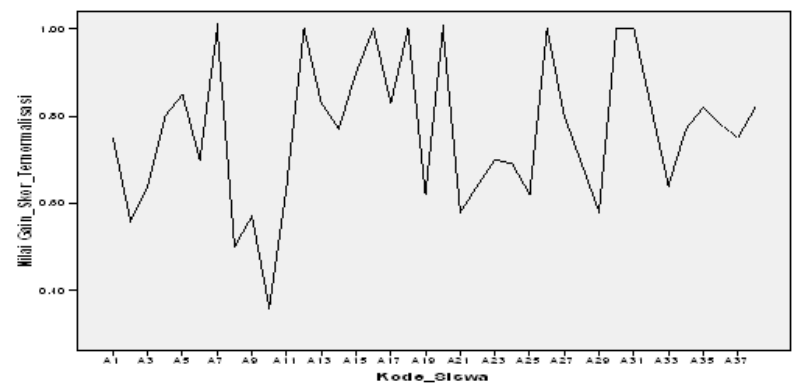

Figure 2 Histograms of Student Group Science Learning Outcomes with the Discovery Learning Model using animation media.

The average normalized gained score of the experimental group compared using the interpretation of normalized gained score is presented in Table 4 below.

Table 4. Interpretation Classification Normalized Gained Score (GSn)

\begin{tabular}{|c|c|}
\hline Percentage of Achievement & Criteria \\
\hline $\mathrm{g}>0.7$ & High \\
\hline $0.3<\mathrm{g}<0.7$ & Moderate \\
\hline $\mathrm{g}<0.3$ & Low \\
\hline
\end{tabular}

Based on the results of the analysis, by comparing the gained average percentage of the normalized score obtained by the Problem Based Learning group of 0.720 , then with the classification of normalized interpretation the average score of 0.720 is in the category $g>0.7$. So it can be concluded that the criterion for the gained normalized average score of the science learning outcomes of the group taught with the Problem-Based Learning model using animated media is classified as high.

\subsubsection{Description of Science Learning Outcomes Data from Groups of students who were taught Conventionally}

The fifth-grade students from SD No. 3 Seminyak is taught conventionally after 8 times at the end of the study students are given a post-test to obtain data on science learning outcomes. After obtaining the post test score, the gained score is sought from the pre-test and post test results.

Table 5. Descriptions of Student Group Science Learning Outcomes Conventional Learning

\begin{tabular}{|l|l|l|l|l|l|l|l|l|}
\hline & N & Range & $\begin{array}{l}\text { Score } \\
\text { Min }\end{array}$ & $\begin{array}{l}\text { Score } \\
\text { Max }\end{array}$ & Sum & Mean & $\begin{array}{l}\text { Std. } \\
\text { Deviation }\end{array}$ & Variance \\
\hline $\begin{array}{l}\text { Gain Normalized } \\
\text { Score }\end{array}$ & 37 & 0.77 & 0.23 & 1.00 & 19.83 & 0.549 & 0.191 & 0.036 \\
\hline Valid N (listwise) & 37 & & & & & & & \\
\hline
\end{tabular}

Based on the data in table 5 , it can be seen that the number of students or $n=37$, the minimum score is 0.23 while the maximum score is 1.00 . Furthermore, Mean is 0.549 , standard deviation is 0.191 , and Variance is 0.036 The science learning outcome data is presented in the form of a histogram of Figure 3 below.

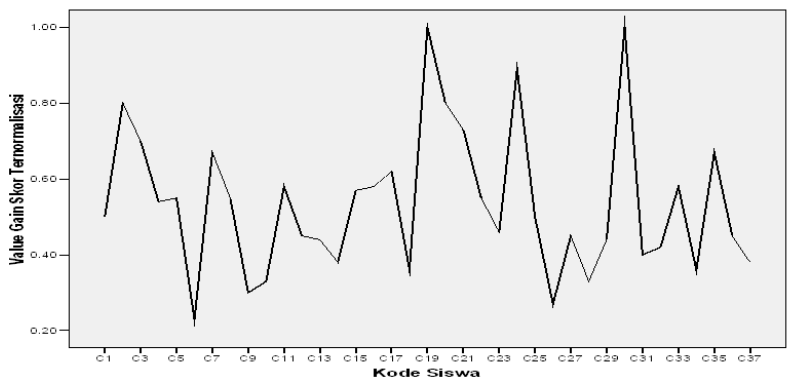

Figure 3. Histograms of Students who were taught Conventionally

The average gained normalized score for the control group compared using the interpretation of the normalized score is presented in table 6 below.

Table 6. Normalized Score Interpretation Classification

\begin{tabular}{|c|c|}
\hline Percentage of Achievement & Criteria \\
\hline $\mathrm{g}>0.7$ & High \\
\hline $0.3<\mathrm{g}<0.7$ & Moderate \\
\hline $\mathrm{g}<0.3$ & Low \\
\hline
\end{tabular}

Based on the above results, by comparing the average percentage of the normalized score obtained by the conventionally learned group is 0.549 then with the classification of normalized interpretation the average score of 0.536 is in the category $0.3<\mathrm{g}<0.7$. So it can be concluded that the criteria for the normalized average score in the science learning outcomes of the control group are classified as moderate.

\subsection{Testing Assumptions}

The assumption test is carried out first before testing the hypothesis using the one-way ANOVA test. The prerequisite test includes the normality test and the homogeneity test of variance as described below. 


\subsubsection{Normality Test}

The normality test was carried out to determine the frequency distribution of scores to test the data on the learning outcomes of science learning groups of students who were taught with the Discovery Learning, ProblemBased Learning and Conventional models using the Kolmogorov-Smirnov test.

Table 7. Result of Normality Test

\begin{tabular}{||l|l|l|l|}
\hline \multirow{2}{*}{$\begin{array}{l}\text { Fifth grade students that was } \\
\text { taught by using a model }\end{array}$} & \multicolumn{3}{|l|}{ Kolmogorov-Smirnova } \\
\cline { 2 - 4 } & Statistics & Df & Sig. \\
\hline Discovery Learning & 136 & 38 & .075 \\
\hline Problem based Learning & 132 & 37 & .103 \\
\hline Conventional & .138 & 37 & .071 \\
\hline
\end{tabular}

From the results of the normality test, it is known that the three models above the Kolmogorov-Smirnof $\mathrm{Sg}$ value $>0.05$, then the science learning outcome data from the three models comes from a normally distributed population.

\subsubsection{Variance Homogeneity Test}

The homogeneity test of variance between groups is intended to ensure that the differences in hypothesis testing actually occur not due to differences within groups but due to differences in variance between groups. The results of the variance homogeneity test are presented in table 8 .

Table 8. Test of Homogeneity of Variances

\begin{tabular}{|l|l|l|l|}
\hline \multicolumn{3}{|l|}{ Gain data normalized scores of Science Learning Outcomes } \\
\hline $\begin{array}{l}\text { Levene } \\
\text { Statistics }\end{array}$ & df1 & df2 & Sig. \\
\hline .248 & 2 & 109 & .780 \\
\hline
\end{tabular}

Based on the results of the variant homogeneity test, it was obtained Sig 0.780>0.05, which means that the data on the results of learning science to the three models used in learning were homogeneous.

\subsection{Hypothesis Testing}

The hypothesis tested in this study is the null hypothesis (H0), namely; There was no significant difference in science learning outcomes between groups of students who were taught using the Discovery Learning model, groups of students who were taught using the Problem-based Learning model, and groups of students who were taught conventionally. Based on the results of the normality and homogeneity test, it can be seen that the data obtained from the experimental group and the control group are normally distributed and have homogeneous variances. The test data has met the prerequisites, hypothesis testing is carried out using oneway Variant Analysis, because there are three means in this study. The results of the calculation of the hypothesis test are presented in the following table.
Table 9. Summary of Analysis of Variance Results to Test Sample Hypotheses

\begin{tabular}{|l|l|l|l|l|l|}
\hline \multicolumn{6}{|c|}{ Gain data normalized scores of Science Learning Outcomes } \\
\hline & $\begin{array}{l}\text { Sum of } \\
\text { Squares }\end{array}$ & df & $\begin{array}{l}\text { Mean } \\
\text { Square }\end{array}$ & F & Sig. \\
\hline $\begin{array}{l}\text { Between } \\
\text { Groups }\end{array}$ & 1,089 & 2 & .545 & 17,865 & .000 \\
\hline $\begin{array}{l}\text { Within } \\
\text { Groups }\end{array}$ & 3,323 & 109 & .030 & & \\
\hline Total & 4,412 & 111 & & & \\
\hline
\end{tabular}

Based on the results of the ANOVA test, it was obtained that Sig $0.000<0.05$, this means that the science learning outcomes data from the three groups were significantly different.

Thus the hypothesis $\mathrm{H} 0$ which states that there is no significant difference in science learning outcomes between groups of students who are taught using the Discovery Learning model, groups of students who are taught using the Problem-based Learning model, and groups of students who are taught conventionally are rejected.

After conducting the one-way analysis of variance test, the next step was to calculate the effectiveness of the learning model to improve science learning outcomes, so Partial Eta Squared was used. Obtained the result of the calculation:

Table 10. Test of Between-Subject Effects

\begin{tabular}{|l|l|l|l|l|l|l|}
\hline Dependent Variable: \\
\hline Source & $\begin{array}{l}\text { Type III Sum } \\
\text { of Squares }\end{array}$ & df & Mean Square & F & Sig. & $\begin{array}{l}\text { Partial Equared } \\
\text { Squa }\end{array}$ \\
\hline Corrected Model & $1.089 \mathrm{a}$ & 2 & .545 & 17,865 & .000 & .247 \\
\hline Intercept & 50,752 & 1 & 50,752 & 1664,954 & .000 & .939 \\
\hline CLASS & 1,089 & 2 & .545 & 17,865 & .000 & .247 \\
\hline Error & 3,323 & 109 & .030 & & & \\
\hline Total & 55,293 & 112 & & & & \\
\hline Corrected Total & 4,412 & 111 & & & & \\
\hline
\end{tabular}

Partial Eta Squared $\left(\eta^{\wedge} 2\right)=0.247$. It can be concluded that the application of the Discovery Learning model and the Problem based Learning model is effective in improving science learning outcomes. When compared with the following Size effect categories;

ICE $\leq 0.20 \ldots \ldots \ldots \ldots$ low effectiveness

$0.20<\mathrm{ES} \leq 0.80 \ldots \ldots$. moderate effectiveness

$0.80<$ ES ............. high effectiveness

Then the Partial Eta Squared coefficient $\left(\eta^{\wedge} 2\right)=0.247$ is classified as moderate.

Based on the results of the data analysis of the science learning outcomes of students who were taught using the Discovery Learning model and students who were taught using the Problem-based Learning model using animated media and students who were taught conventionally differed significantly. This is shown by the results of data analysis using One-Way Analysis of Variance which is obtained $\mathrm{F}=17,865 \mathrm{Sig} 0.000<0.05,5 \%$ significance level. This difference can also be seen from the average 
score of science learning outcomes in groups of students who are taught using the Discovery Learning model $=0.764>=0.720$ groups that are taught with a problembased learning model $>=0.549$ groups that are taught conventionally. The higher average score in the experimental group than the control group is because in the learning process, the experimental group gets treatment by applying the Discovery Learning model and the Problem-based Learning model. Both models are learning models that make students active in investigating and finding concepts from the problems given by the teacher. This is very different from the control group that was taught using conventional learning.

The results of this study are in line with the results of the meta-analysis research conducted by Yuliana (2018) related to the use of the Discovery Learning model of six research results published in national journals. From the research conducted, it is proven that the Discovery Learning model is able to help increase student activeness in the learning process with students finding their own information so that it shows an increase in student learning outcomes in both elementary schools and above education levels [11].

In good application, Discovery Learning models and Problem-based Learning models both use animated media. Animation is multimedia that can convey information and learning content in the form of animated images combined with text, sound, attractive colors to create animated videos that are in accordance with learning material. The use of media in learning will make it easier for students to concretize abstract concepts. The material taught in this experimental research is about the respiratory system which is an abstract concept. Animated media besides attracting students' attention can also turn abstract concepts into concrete.

Based on the research that has been done, it is observed that the discovery learning model in its implementation combined with animation media makes students active in the learning process. Students found their own information based on observations of animation media. The media used attracts students' attention and allows the formation of abstract concepts that have easy-to-understand meanings. Students get the opportunity to be directly involved in learning activities. Students are trained to actively learn independently. Something that is gained by finding yourself is longer remembered. The discovery learning model is a model for developing an active learning method by discovering it yourself, investigating it yourself, so that the results obtained will be faithful and durable in memory [12].

After testing the hypothesis with one-way ANOVA analysis then continued testing to measure the effectiveness of the treatment given the effect of improving science learning outcomes is used, namely the formula Partial Eta Squared $\left(\eta^{\wedge} 2\right)$ with the results obtained by the amount of effectiveness of 0.247 . So it can be concluded that the application of the learning model has an effect in improving the competence of science in the medium category.

\section{CONCLUSION}

Based on the results of research data analysis and discussion, it can be concluded as follows.

1. There is a significant difference in science learning outcomes between groups of students who are taught using the Discovery Learning model using animated media, groups of students who are taught using the Problem-based Learning model, and groups of students who are taught conventionally. This is proved by the results of the One-Way Analysis of Variance which is obtained $\mathrm{F}=17,865 \mathrm{Sig} 0.000$ $<0.05,5 \%$ significance level.

2. The application of the Discovery Learning model uses animated media and the Problem-based Learning model uses animated media effectively to improve science learning outcomes shown by Partial Eta Squared $\left(\eta^{\wedge} 2\right)=0.247$ with a relatively moderate effect size.

\section{AUTHORS' CONTRIBUTIONS}

This research is expected to produce an effective learning model to improve science learning outcomes. In addition, this research gives insight and direct experience on how to improve students' science skills through models of Discovery Learning and Problem-based Learning particularly for students in elementary school.

\section{ACKNOWLEDGMENTS}

This research was supported by a grant from LPPM Universitas Pendidikan Ganesha and sponsored by DIPA BLU Nomor: SP DIPA-023.17.2.677530/2020

\section{REFERENCES}

[1] Ainamulyana, Pembelajaran Abad 21 dan Kurikulum 2013, 2017. Available on https://ainamulyana.blogspot.com/2017/03/pembel ajaran-abad-21-dan-kurriculum-2013.html (accessed February 16, 2020)

[2] M. Nugroho, Komparasi Model Pembelajaran Discovery Learning Dan Problem Solving Ditinjau Dari Hasil Belajar Tematik Kelas 4 Sekolah Dasar, Jurnal Ilmiah Pendidikan dan Pembelajaran PPs Universitas Pendidikan Ganesha JIPP, Volume 2 Nomor 2 Juli, 2018.

[3] R. F. Kusumadewi, Efektivitas Model Pembelajaran Discovery Learning terhadap Kemampuan Literasi Matematika Disekolah dasar. 
[4] A. Kodir, Manajemen Pembelajaran Saintifik Kurikulum 2013, Bandung: Pustaka Setia, 2018.

[5] Kunandar, Penilaian Autentik (Penilaian Hasil Belajar Peserta Didik Berdasarkan Kurikulum 2013, Jakarta: PT Rajagrafindo Persada, 2014.

[6] Z. Amir, and Risnawati, Psikologi Pembelajaran Matematika, Yogyakarta: Aswaja Pressindo, 2013.

[7] B. A. Pribadi, Media dan Teknologi dalam Pembelajaran, Jakarta: Kencana, 2017.

[8] A. Ruslan, Animasi Perkembangan dan Konsepnya, Bogor: Ghalia Indonesia, 2016.

[9] M. Yusuf, Asesmen dan Evaluasi Pendidikan, Jakarta: Prenadamedia Group, 2015.

[10] Sugiyono, Metode Penelitian, Bandung: Alfabeta Bandung, 2018.

[11] Y. Nabila, Penggunaan Model Pembelajaran Discovery Learning Dalam Peningkatan Hasil Belajar Siswa Di Sekolah Dasar, Jurnal Ilmiah Pendidikan dan Pembelajaran P-ISSN: 1858-4543, E-ISSN: 2615-6091 PPs Universitas Pendidikan Ganesha, 2018.

[12] Hosnan, Pendekatan Saintifik dan Kontekstual dalam pembelajaran Abad 21, Bogor: Ghalia Indonesia, 2014. 